\title{
Is there evidence to link acid reflux with chronic sinusitis or any nasal symptoms? A review of the evidence*
}

\author{
E.P. Flook ${ }^{1}$ and B.N. Kumar ${ }^{2}$ \\ ENT Registrar North Western Deanery, Hope Hospital, Salford Royal Foundation NHS Trust, United \\ Kingdom \\ 2 ENT Consultant, Royal Albert Edward Infirmary, Wrightington, Wigan and Leigh NHS Trust, Wigan, \\ United Kingdom
}

\begin{abstract}
SUMMARY Background: Acid reflux into the oesophagus, larynx, pharynx or nasopharynx has been suggested as a causal factor in chronic rhino-sinusitis (CRS), which can then be refractory to nasal treatments. The aim of this review was to conclude on the strength of the link between GORD, LPR, nasopharyngeal reflux, nasal symptoms and CRS.

Method: Medline and Embase search.

Results: Nineteen papers describing varying studies on CRS, GORD, LPR and PPI therapy were found. Four adult case-controlled studies showed more acid reflux events/symptoms in refractory CRS patients. Paediatric cohort studies showed more reflux events in rhinosinusitis patients than the general paediatric population, but they are not conclusive. Many papers do not use robust CRS diagnostic criteria for inclusion into studies and take no confounding factors into consideration.

Conclusion: The evidence of a link is poor with no good randomised controlled trials available. The few adult studies that show any link between acid reflux and nasal symptoms are small case-controlled studies with moderate levels of potential bias. There is not enough evidence to consider anti-reflux therapy for adult refractory CRS and there is no evidence that acid reflux is a significant causal factor in CRS.
\end{abstract}

Key words: reflux, rhinosinusitis, nasal symptoms, pH monitoring, LPR, GORD

\section{INTRODUCTION}

It has been questioned whether acid reflux (gastroesophageal reflux (GORD) and laryngopharyngeal reflux (LPR)) can lead to many different nasopharyngeal symptoms, which in combination can mimic chronic rhinosinusitis (CRS). There is debate as to whether acid reflux is a causal factor in CRS and also whether anti-reflux therapy can improve symptoms of refractory CRS. Similar symptoms can be described in GORD, LPR, and CRS conditions and clinical confusion with regard to the correct diagnosis can lead to inadequate or sometimes inappropriate management.

Acid reflux and nasal symptoms have been the focus of a wide variety of papers in the past that are not suitable for a meta-analysis review due to the different variables measured and techniques used. The aim of this review was to gather all the published evidence around this subject, evaluate the quality and relevance, and conclude on the strength of the link between GORD, LPR, nasopharyngeal reflux and nasal symptoms and CRS and discuss how the clinician would best use this evidence in their own practice.

In a paediatric population, gastroesophageal reflux disease (GORD) is associated with an increase in the risk of sinusitis, laryngitis, asthma, pneumonia, and bronchiectasis ${ }^{(1)}$. There is no large unbiased randomised controlled trial from which we can take reliable evidence to demonstrate this link. Small studies make suggestions only, which makes it difficult for the clinician to apply the results to their own patients. Up to $10 \%$ of infants can have GORD ${ }^{(2)}$ while children older than 12 months should have a similar rate of GORD as adults ${ }^{(2,3)}$. Smaller studies not accounting for age and confounding factors (weight, food before sleeping, sleeping position, asthma) have shown much higher rates of reflux with $25 \%$ of asymptomatic children having GORD and $8 \%$ having nasopharyngeal reflux ${ }^{(4)}$. 


\section{SEARCH METHOD}

Published studies were identified using Medline (1950 - July 2009) and EMBASE (1980 - July 2009). Search terms used included: 'gastroesophageal reflux', 'GERD', 'GORD', 'laryngopharyngeal reflux', 'nasopharyngeal reflux', 'acid laryngitis', 'chronic rhinosinusitis', 'chronic sinusitis', 'CRS', 'post nasal drip', and 'nasal symptoms'. Searches were not restricted by language. Reference lists from identified articles were searched and cross-referenced to obtain further relevant articles.

This and other such literature reviews are of course at risk of publication bias through non-inclusion of unpublished studies with non-significant or less impressive results.

The identified studies were assessed for eligibility and included only if they explored an association between nasal symptoms and acid reflux.

The identified studies were individually assessed using the Critical Appraisal Skills Programme (Oxford, UK) tools ${ }^{(5)}$. The papers were then stratified into low, moderate and high risk of bias and quality of study.

CRS has many symptoms associated with it. Some symptoms are more indicative of sinus pathology (green rhinorrhoea with nasal congestion) whereas others are much less specific to their aetiology (post-nasal drip, facial pain, nasal obstruction). The EPOS paper defines rhinosinusitis as inflammation of the nose and the paranasal sinuses characterised by a combination of symptoms and signs ${ }^{(6)}$ (Table 1). Although we should all strictly adhere to these criteria when diagnosing CRS, it is easy to label a patient with CRS when they have a vague symptom profile or with an emphasis on the less specific symptoms. Validated symptom scores exist and can be used to demonstrate symptom severity and change after treatment.

Gastric enzymes and acid inflame the larynx and pharynx causing LPR. Symptoms can include hoarseness, chronic cough and throat clearing but also more subjective symptoms like globus sensation or sensation of excessive or thick mucus and post-nasal drip. Symptoms can be scored on the Reflux Symptom Index ${ }^{(7)}$ (Table 2) which can be used to aid diagnosis and again can be used to assess treatment outcomes but should not be relied on, as the scores are a summation of subjective responses. Signs within the larynx include posterior commissure oedema and arytenoid swelling. Acid reflux into the hypopharynx can easily reflux into the nasopharynx especially

Table 1. EPOS clinical definition of rhinosinusitis ${ }^{(6)}$

\begin{tabular}{ll}
\hline Symptoms & $\begin{array}{l}\text { either nasal blockage / obstruction / congestion or } \\
\text { nasal discharge (anterior / posterior nasal drip) } \\
\pm \text { facial pain/pressure } \\
\\
\pm \text { reduction or loss of smell }\end{array}$ \\
\hline Endoscopic & $\begin{array}{l}\text { polyps and / or } \\
\text { mucopurulent discharge primarily from middle meatus } \\
\text { signs }\end{array}$ \\
& $\begin{array}{l}\text { and / or } \\
\text { oedema / mucosal obstruction primarily in middle } \\
\text { meatus }\end{array}$ \\
\hline and / or & mucosal changes within the ostiomeatal complex \\
CT changes & sinuses.
\end{tabular}

Table 2. Reflux Symptom Index $(\mathrm{RSI})^{(7)}$. A RSI $>10$ could indicate significant laryngopharyngeal reflux.

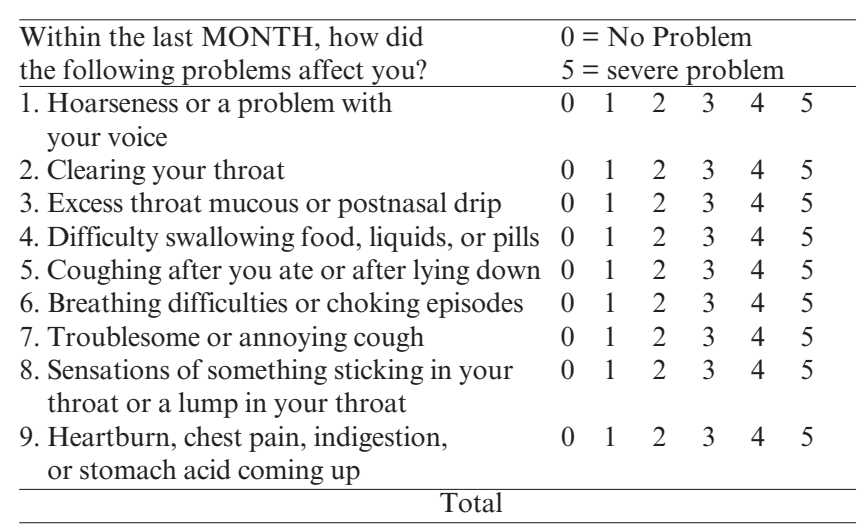

when lying flat, but the effect of this is unknown. GORD has different symptoms and treatment regimes and should be considered as a separate entity from LPR, where possible.

$\mathrm{pH}$ probe testing can be performed to objectively measure acid reflux into oesophagus or using dual monitoring probes can measure reflux into the hypopharynx or nasopharynx for comparison and assessment of the level of reflux.

\section{SEARCH RESULTS}

\section{Identified studies}

Nineteen studies were identified that were suitable. Seven specifically looked at paediatric cases and 12 used $\mathrm{pH}$ oesophageal probes to objectively detect gastroesophageal, laryngopharyngeal or nasopharyngeal reflux.

The literature search identified only 1 randomised controlled trial and all other papers were prospective cohort trials with or without controls (evidence grade II a and II b) or retrospective case analyses (evidence grade III).

Quality of the papers and level of potential bias in their results showed that all papers have moderate or high risk of bias (Table 3 and 4).

The variety of papers using different techniques, criteria and investigating different angles of this problem means that most of the papers cannot be directly compared to each other.

\section{Paediatric studies}

The paediatric studies (Table 3) consisted of 4 studies using $\mathrm{pH}$ studies and 4 studies trialling anti-reflux therapy.

pH studies

Phipps found 19 of $30(63 \%)$ children to have GORD from a population of children with medically refractory CRS with evidence of sinus disease on CT scanning, being on intranasal steroids throughout (8). Monteiro showed that $10 \%$ of children with a diagnosis of CRS (made clinically with additional plain x-ray or CT scans) also have gastroesophageal reflux. However, this was a small group of 10 and so only 1 child showed a correlation between CRS and GORD that is not 


\begin{tabular}{|c|c|c|c|c|c|c|}
\hline Study & Type & Study size & Selection criteria & Measurement & Bias risk & Result \\
\hline Phipps et al. $2000^{(8)}$ & Cohort & 30 & $\begin{array}{l}\text { Consecutive } \\
\text { CRS clinically }+ \\
\text { evidence on CT }\end{array}$ & $\begin{array}{l}\text { Oesophageal }+ \\
\text { nasopharyngeal pH } \\
\text { monitoring }\end{array}$ & $\bmod$ & $\begin{array}{l}19 \text { had GORD, } 6 \\
\text { also had } \\
\text { nasopharyngeal } \\
\text { reflux }\end{array}$ \\
\hline Monteiro et al. 2005(9) & Cohort & 10 & $\begin{array}{l}\text { selected clinically / } \\
\text { radiologically CRS }\end{array}$ & $\begin{array}{l}\text { Oesophageal } \mathrm{pH} \\
\text { monitoring }\end{array}$ & high & $\begin{array}{l}1 \text { of } 10 \text { had } \\
\text { significant GORD }\end{array}$ \\
\hline Barbero $1996^{(10)}$ & Cohort & 22 & $\begin{array}{l}\text { Selected clinically indicated } \\
\text { to undergo sinus surgery } \\
\text { for CRS }\end{array}$ & $\begin{array}{l}\text { Oesophageal } \mathrm{pH} \\
\text { monitoring }+ \\
\text { improvement after } \\
\text { anti-reflux therapy } \\
\text { treatment }\end{array}$ & $\bmod$ & $\begin{array}{l}16 \text { had GORD. } \\
10 \text { improved } \\
\text { with anti-reflux } \\
\text { therapy }\end{array}$ \\
\hline Keles et al. $2005^{(6)}$ & $\begin{array}{l}\text { Prospect } \\
\text { ive case } \\
\text { - control }\end{array}$ & $\begin{array}{l}30 \\
\text { vs } \\
12\end{array}$ & $\begin{array}{l}\text { Adenoid hyperplasia } \\
\text { vs normal }\end{array}$ & $\begin{array}{l}\text { Upper and lower } \\
\text { oesophageal pH } \\
\text { monitoring }\end{array}$ & mod & $\begin{array}{l}\text { LPR } 47 \text { vs } 8 \% \\
\text { GORD } 65 \text { vs } 25 \%\end{array}$ \\
\hline Bothwell et al. $1999^{(12)}$ & $\begin{array}{l}\text { Retrospective } \\
\text { case series }\end{array}$ & 28 & $\begin{array}{l}\text { Selected clinically indicated } \\
\text { to undergo sinus } \\
\text { surgery for CRS }\end{array}$ & $\begin{array}{l}\text { subjective symptoms } \\
\text { and surgery } \\
\text { avoidance after } \\
\text { anti-reflux therapy }\end{array}$ & high & $\begin{array}{l}25 \text { of } 28 \text { improved } \\
\text { enough to avoid } \\
\text { sinus surgery }\end{array}$ \\
\hline Halstead $^{(13)}$ & Case series & 11 & $\begin{array}{l}\text { Rhinitis, sinusitis and } \\
\text { otitis patients having } \mathrm{pH} \\
\text { testing }\end{array}$ & $\begin{array}{l}\mathrm{pH} \text { testing and symptoms } \\
\text { after antireflux } \\
\text { medication }\end{array}$ & high & $\begin{array}{l}6 \text { of } 11 \text { improved } \\
\text { with treatment }\end{array}$ \\
\hline Mengale et al. $2006^{(14)}$ & $\begin{array}{l}\text { Retrospective } \\
\text { Case series }\end{array}$ & 45 & GORD + nasal symptoms & $\begin{array}{l}\text { Nasal symptom } \\
\text { improvement after } \\
\text { anti-reflux and other } \\
\text { treatments }\end{array}$ & high & $\begin{array}{l}80-85 \% \text { nasal } \\
\text { symptoms improved }\end{array}$ \\
\hline
\end{tabular}

significantly different from normal population (9). Barbero tested 22 children already on the waiting list for sinus surgery showing 16 (73\%) had significant GORD, with 9 (41\%) having no specific GORD symptoms i.e. silent reflux ${ }^{(10)}$.

Phipps also found $20 \%$ of the CRS children to have nasopharyngeal reflux ${ }^{(8)}$.

Children with adenoid hyperplasia had more reflux than "normal" children with dual probe $\mathrm{pH}$ monitoring at distal and proximal oesophagus, the authors assuming pharyngeal reflux if upper oesophagus is involved (LPR $46 \%$ vs $8 \%$ and GORD $63 \%$ vs $25 \%)^{(6)}$. Although a histological analysis of adenoidal tissue showed no pepsin within hyperplastic adenoids thereby claiming there is little evidence that reflux is a major cause of adenoidal hyperplasia ${ }^{(11)}$.

\section{Anti-reflux therapy studies}

When treatment with anti-reflux therapy was trialled in CRS children, $45 \%{ }^{(10)}$ and $89 \%{ }^{(12)}$ improved. Bothwell's retrospective study commented that $89 \%$ of patients awaiting sinus surgery for CRS no longer required surgery following antireflux therapy. This does not take into account any other factor of why the surgery was avoided, (i.e. natural resolution, seasonal variation or other nasal therapies) nor how long the anti-reflux therapy was taken or their compliance ${ }^{(12)}$. Barbero found that of 22 children with medically refractory CRS suitable for sinus surgery, 13 improved (10 completely) with anti reflux therapy ${ }^{(10)}$.

Treatment of nasal symptoms with anti-reflux therapy has shown some success but diagnostic criteria or good trial meth- odology was lacking. In Halstead's study, $55 \%$ of patients had improved symptoms with anti-reflux therapy but this study of 11 children included rhinitis, sinusitis or otitis patients with no clear diagnostic criteria or any comment on the degree of improvement ${ }^{(13)}$. Mengale saw retrospectively that GORD patients aged 3 months to 12 years ( $\mathrm{pH}$ probe proven) treated with antireflux drugs, antiallergic drugs, and surgical procedures therapy saw their nasal obstruction improve in $85 \%$ of cases and nasal secretions improve in $80 \%$ and nasal itching in $80 \%{ }^{(14)}$. These children were not diagnosed with CRS and may well have had rhinitis which would have responded to these treatments regardless of any GORD.

\section{Adult studies}

In the adult studies, there was only 1 randomised controlled study (evidence level I). In 5 case controlled studies (level II a), different factors were examined using $\mathrm{pH}$ probes (nasopharyngeal, hypopharynx as well as oesophageal placement), pepsin level analysis and quality of life questionnaires. Other adult studies were 6 non-controlled cohort studies (level II b) (Table 4).

\section{pH studies}

LPR events were more frequent in the CRS group when compared to a non-CRS group ( $88 \%$ vs $55 \%{ }^{(15)}, 76 \%$ vs $24 \%$ (16) and $64 \%$ vs $\left.18 \%{ }^{(17)}\right)$. When a $\mathrm{pH}$ probe was used in the nasopharynx, it showed acid $(\mathrm{pH}<5)$ reflux events to be higher in refractory CRS patients ( $74 \%$ vs. $38 \%)^{(16)}$. Although these studies were controlled, there was no comment on matching 


\begin{tabular}{|c|c|c|c|c|c|c|}
\hline Study & Type & Study size & Selection criteria & Measurement & Bias risk & Result \\
\hline Ozman et al. $2005^{(15)}$ & $\begin{array}{l}\text { Case- } \\
\text { controlled }\end{array}$ & 33 vs 20 & $\begin{array}{l}\text { Awaiting sinus surgery } \\
\text { for CRS vs no CRS }\end{array}$ & $\begin{array}{l}\text { Pharyngeal } \mathrm{pH} \mathrm{g} \\
\text { monitorin and pepsin } \\
\text { nasal lavage }\end{array}$ & $\bmod$ & $\begin{array}{l}\text { More reflux in CRS } \\
\text { group + more nasal } \\
\text { pepsin }\end{array}$ \\
\hline $\begin{array}{l}\text { DelGaudio et al. } \\
2005^{(16)}\end{array}$ & $\begin{array}{l}\text { Case- } \\
\text { controlled }\end{array}$ & $\begin{array}{l}38 \text { vs } 10 \\
\text { vs } 20\end{array}$ & $\begin{array}{l}\text { Surgically refractory CRS } \\
\text { vs resolved CRS } \\
\text { vs no CRS }\end{array}$ & $\begin{array}{l}\text { Nasal, pharyngeal } \\
\text { and oesophageal } \\
\text { pH monitoring }\end{array}$ & $\bmod$ & $\begin{array}{l}\text { More reflux in } \\
\text { refractory CRS } \\
\text { group }\end{array}$ \\
\hline $\begin{array}{l}\text { Ulualp SO et al. } \\
1999^{(17)}\end{array}$ & $\begin{array}{l}\text { Case- } \\
\text { controlled }\end{array}$ & 11 vs 11 & Refractory CRS vs no CRS & $\begin{array}{l}\text { Pharyngeal and } \\
\text { oesophageal } \mathrm{pH} \\
\text { monitoring }\end{array}$ & $\bmod$ & $\begin{array}{l}\text { CRS: } 7 \text { of } 11 \text { had } \\
\text { pharyngeal reflux } \\
\text { events } \\
\text { No CRS: } 2 \text { of } 11\end{array}$ \\
\hline$\overline{\text { Wong et al. } 2004^{(18)}}$ & Cohort & 37 & CRS & 4 channel $\mathrm{pH}$ probe & mod & $\begin{array}{l}32 \% \text { had GORD. } \\
\text { LPR and } \\
\text { nasopharyngeal } \\
\text { reflux rare }\end{array}$ \\
\hline Jecker et al.2005 & $\begin{array}{l}\text { Case- } \\
\text { controlled }\end{array}$ & 20 vs 20 & Recurrent CRS vs no CRS & $\mathrm{pH}$ monitoring & $\bmod$ & $\begin{array}{l}\text { More GORD in } \\
\text { CRS group but not } \\
\text { more LPR. }\end{array}$ \\
\hline $\begin{array}{l}\text { Kibblewhite et al. } \\
1990^{(20)}\end{array}$ & RCT & 20 & Post-nasal drip or globus & $\begin{array}{l}\text { Symptom improvement } \\
\text { with PPI or placebo }\end{array}$ & high & No difference \\
\hline $\begin{array}{l}\text { Kleemann et al. } \\
2005^{(21)}\end{array}$ & Cohort & 79 & $\begin{array}{l}3 / 52 \text { Post FESS nasal } \\
\text { symptoms }\end{array}$ & Symptoms after $2 / 52$ PPI & high & $\begin{array}{l}60 \text { of } 79 \text { improved } \\
\text { nasal symptoms }\end{array}$ \\
\hline DiBiase et al. $2002^{(22)}$ & Cohort & 11 & Consecutive clinical CRS & $\begin{array}{l}\text { Symptoms scoring. } \\
\text { nasolayngoscopy after } \\
\text { PPI therapy }\end{array}$ & $\bmod$ & $\begin{array}{l}\text { Some symptom } \\
\text { improvement, not } \\
\text { correlated with } \\
\text { appearances }\end{array}$ \\
\hline $\begin{array}{l}\text { Pincus RL et al. } \\
2006^{(23)}\end{array}$ & Cohort & 30 & $\begin{array}{l}\text { Medically and surgically } \\
\text { refractory CRS }\end{array}$ & $\begin{array}{l}\mathrm{pH} \text { monitoring and } \\
\text { symptom improvement } \\
\text { using PPI }\end{array}$ & high & $\begin{array}{l}25 \text { of } 30 \text { had LPR or } \\
\text { Nasal reflux events. } \\
14 \text { of } 15 \text { improved } \\
\text { with PPI }\end{array}$ \\
\hline Dinis et al. $2006^{(24)}$ & $\begin{array}{l}\text { Case- } \\
\text { controlled }\end{array}$ & 15 vs 5 & $\begin{array}{l}\text { Medically refractory CRS } \\
\text { vs no CRS }\end{array}$ & $\begin{array}{l}\text { Biopsy analysis for pepsin } \\
+ \text { H. pylori }\end{array}$ & high & $\begin{array}{l}\text { No intranasal pepsin } \\
\text { identified. } \\
\text { No difference in } \\
\text { H.pyori between } \\
\text { groups }\end{array}$ \\
\hline $\begin{array}{l}\text { Delehaye et al. } \\
2009^{(25)}\end{array}$ & Cohort & 50 & GORD & $\begin{array}{l}\text { Saccharin test time } \\
\text { + nasal symptom } \\
\text { scoring }\end{array}$ & $\bmod$ & $\begin{array}{l}37 \text { of } 50 \text { had } \\
\text { prolonged nasal } \\
\text { mucociliary } \\
\text { clearance time. All } \\
\text { normal SNOT20 } \\
\text { scores. }\end{array}$ \\
\hline \multirow[t]{2}{*}{ Wise et } & \multirow[t]{2}{*}{ Mixed cohor } & 68 & $\begin{array}{l}\text { Refractory CRS \& } \\
\text { resolved CRS \& }\end{array}$ & $\begin{array}{l}\text { Nasal, pharyngeal } \\
\text { and oesophageal }\end{array}$ & $\bmod$ & $\begin{array}{l}\text { More reflux seen in } \\
\text { patients complain- }\end{array}$ \\
\hline & & & no CRS & $\begin{array}{l}\text { pH monitoring. } \\
\text { Post nasal drip } \\
\text { symptom scoring }\end{array}$ & & of post nasal drip. \\
\hline
\end{tabular}

the controls to eliminate significant confounding effects such as age, weight, medications, co-morbidities or hiatus hernia. In a different study of CRS patients, a 4-channel $\mathrm{pH}$ probe showed $32 \%$ patients had GORD but LPR was rare and nasopharyngeal reflux was very rare ${ }^{(18)}$.

The relationship of CRS with gastroesophageal reflux has also been studied. A cohort of recurrent CRS patients had 10 times as many gastroesophageal reflux events compared with nonCRS patients but these differences were not seen in the acid reflux measured in their hypopharynx. However, this study chose to look at patients with CRS with polyps, which is a significantly different cohort to refractory CRS without polyps (19).

\section{Anti-reflux therapy studies}

When treatment with a proton pump inhibitor (PPI) was trialled, cimetidine had no benefit over a placebo to globus or postnasal drip symptoms ${ }^{(20)}$. This trial had only 20 patients $(9$ and 11 in each arm with poor group matching for post nasal drip symptoms). The patients did not have CRS or $\mathrm{pH}$ testing to prove the reflux; they monitored globus, postnasal drip, 
chronic throat clearing and heartburn using a non-validated symptom scoring system. Treatment was with cimetidine 300 mg qds po, which is rarely used in current practice. This trial has many failings with significant bias and should not be used in a discussion on this topic.

Kleeman's study started PPI treatment if patients still had CRS symptoms 3 weeks after FESS and found that PPIs helped nasal symptoms in $76 \%$ of patients ${ }^{(21)}$. This study did not account for continued symptom improvement that can occur naturally beyond 3 weeks after FESS nor was there any comment on whether any other medical nasal treatment was used. A small study with regular heartburn, but not CRS, showed that $25-84 \%$ of patients had nasal symptom improvement ${ }^{(22)}$. Fourteen out of $15(93 \%)$ patients with refractory nasal congestion, discharge or facial pain/headaches had improvement of these symptoms with PPI treatment for 1 month ${ }^{(23)}$. In 7 of these patients their symptoms resolved completely although subjective symptom scoring and recall bias may be factors.

\section{Nasal testing}

When pepsin levels were taken by nasal lavage using flurometric assay, they correlated well with reflux events ${ }^{(15)}$. Pepsin levels were not raised in medically refractory CRS patients from another study that biopsied inflamed sino-nasal tissue ${ }^{(24)}$.

Thirty seven out of 50 patients with GORD without CRS had prolonged nasal saccharin test compared to normal values ${ }^{(25)}$. This demonstrates an objective link. Those with gastroesophageal symptoms had higher SNOT-20 scores compared to those without symptoms, but not high enough to be truly abnormal.

\section{Symptom questionnaires}

Patients (CRS and Non-CRS) with LPR and nasopharyngeal reflux as shown by $\mathrm{pH}$ probe testing had statistically significantly more postnasal drip symptoms when measured by the SNOT20 and MRSI questionnaires (Sinonasal Outcome Test20 and Modified Reflux Symptom Index ${ }^{(22)}$. This study used a mixed cohort of refractory CRS, resolved CRS and non-CRS patients and studied them all together. It established no difference between the patient groups and had some strange subgroup results that reflux of $\mathrm{pH}<4$ did not cause symptoms but a milder $\mathrm{pH}<5$ was significant.

\section{DISCUSSION}

The different studies, inclusion criteria, testing techniques and varied treatment regimes make comparison, analysis and conclusions difficult. There are no scientifically high quality papers on this subject. This alone demonstrates that the evidence of a link is weak. There are a few case-controlled papers that are mostly well constructed but confounding factors are not eliminated. Table 4 shows that on analysis all the papers had moderate or high risk of bias. It is uncertain that all patients within these studies fulfilled the EPOS definition of CRS (most were published before EPOS) and may have had less stringent criteria.

However, several studies have similar findings. Four studies of patients with CRS showed positive $\mathrm{pH}$ tests confirming
GORD, LPR or nasopharyngeal events in a higher percentage than the incidence in non-CRS patients. Also 3 papers showed that some nasal symptoms improve with anti-reflux therapy but treatment regimes, symptom groups and level of improvements were vague and variable. There is no evidence that true refractory CRS is resolved by anti-reflux therapy to any significant extent.

Treatment of LPR is not standardised with proton pump inhibitors (PPIs) being used regularly with little evidence and there are opinions that the use of alginates, barrier protection and anti-inflammatories are more effective. This makes trials just using PPIs as treatment questionable and potentially redundant. There were no studies of nasal symptoms using other anti reflux therapy other than PPIs or H2 antagonists.

The proven presence of peptic enzymes on nasal mucosa and the presence of stomach acid causing nasal mucociliary hypofunction may cause some symptoms but there is no evidence of reflux being a causal factor in chronic rhinosinusitis.

In the paediatric studies, the variability in the results comes from the low numbers used in these studies (mean $=22.5$ ), no controls, the varying diagnostic criteria for CRS in children, GORD diagnostic criteria, selection and data collection bias and other confounding factors such as age, weight, co-morbidity and meals before bedtime. There are no randomised controlled studies and Table 3 shows that on analysis 4 out of the 6 paediatric papers had high risk of bias. As a result of this poor methodology of the papers, good conclusions regarding paediatric cases cannot come from the available evidence at present.

\section{CONCLUSION}

In refractory cases of CRS, acid reflux should be kept in mind as the manifestations of CRS and LPR/GORD are so protean as to cause confusion in the diagnosis, and anti-reflux therapy may help for some symptoms. There is no evidence in the literature currently to show a causal link between these very common clinical conditions. Anti reflux treatment should be started if there is clinical or $\mathrm{pH}$ probe testing evidence of reflux, but not on nasal symptoms alone.

Some paediatric CRS studies show GORD rates in CRS children to be well above the expected prevalence of GORD in the normal paediatric population, but they are not conclusive. Anti reflux treatment in children should be considered on an individual's symptoms rather than instituting PPI therapy for all CRS patients on this evidence.

Future studies must have robust inclusion criteria to ensure any results can be applied to the correct subset of rhinology patients. Further there must be a correctly randomized controlled trial with sufficient numbers in each group to show that intervention produced a significant difference. The trial should also make note of the inclusion of barrier protection and conservative / lifestyle changes advice in any treatment regimes. 


\section{AUTHOR CONTRIBUTIONS}

E.P. Flook: researcher, author and B.N. Kumar: supervisor, editor

\section{CONFLICT OF INTEREST}

None declared

\section{REFERENCES}

1. El-Serag HB, Gilger M, Kuebeler M, et al. Extraesophageal associations of gastroesophageal reflux disease in children without neurologic defects. Gastroenterology 2001; 121: 1294-1299.

2. Vandenplas Y, Sacre-Smits L. Continuous 24-hour esophageal $\mathrm{pH}$ monitoring in 285 asymptomatic infants $0-15$ months old. J Pediatr Gastroenterol Nutr. 1987; 6: 220-224

3. Schindlbeck NE, Heinrich C, Konig A. Optimal thresholds sensitivity and specificity of long-term $\mathrm{pH} /$ metry for the detection of gastroesophageal reflux disease. Gastroenterology 1987; 93: 85-90.

4. Keles B, Ozturk K, Arbag H, et al. Frequency of pharyngeal reflux in children with adenoid hyperplasia. Int J Pediatr Otorhinolaryngol 2005; 69: 1103-7.

5. Critical Appraisal Skills Programme, Oxford, UK http://www. phru.nhs.uk/Pages/PHD/resources.htm. [accessed on $20 \mathrm{Aug}$ 2009]

6. Fokkens W, Lund V, Mullol J. EP3OS European position paper on rhinosinusitis and nasal polyps. A summary for the otorhinolaryngologists. Rhinology 2007; 45: 97-101.

7. Belafsky PC, Postma GN, Koufman JA. Validity and reliability of the reflux symptom index (RSI). J Voice 2002; 16: 274-277.

8. Phipps CD, Wood WE, Gibson WS, et al. Gastroesophageal reflux contributing to chronic sinus disease in children. Arch Otolaryngol - Head and Neck Surg 2000; 126: 831-836.

9. Monteiro VRSG, Sdepanian VL, Weckx L, et al. Twenty-fourhour esophageal $\mathrm{pH}$ monitoring in children and adolescents with chronic and/or recurrent rhinosinusitis. Braz J Med Biol Res. 2005; 38: 215-220

10. Barbero GJ. Gastroesophageal reflux and upper airway disease. Otolaryngol Clin North Am. 1996; 29: 27-38.

11. Harris PK, Hussey DJ, Watson DI, et al. Reflux changes in adenoidal hyperplasia: a controlled prospective study to investigate its aetiology. Clin Otol 2009; 34: 120-126.

12. Bothwell MR, Parsons DS, Talbot A, et al. Outcome of reflux therapy on pediatric chronic sinusitis. Otolaryngol - Head Neck Surg 1999; 121: 255-262.

13. Halstead LA. Role of gastroesophageal reflux in pediatric upper airway disorders. Otolaryngol - Head Neck Surg 1999; 120: 208214

14. Megale SRMCL, Scanavini ABA, Andrade EC, et al. Gastroesophageal reflux disease: Its importance in ear, nose, and throat practice.Int J Pediat Otorhinolaryngol 2006; 70: 81-88.

15. Ozmen S, Yücel OT, Sinici I, et al. Nasal pepsin assay and $\mathrm{pH}$ monitoring in chronic rhinosinusitis. Laryngoscope 2008; 118: 890-894.

16. DelGaudio JM. Direct nasopharyngeal reflux of gastric acid is a contributing factor in refractory chronic rhinosinusitis. Laryngoscope 2005; 115: 946-957.

17. Ulualp SO, Toohill RJ, Hoffmann R, et al. Possible relationship of gastroesophagopharyngeal acid reflux with pathogenesis of chronic sinusitis. Am J Rhinol. 1999; 13: 197-202.

18. Wong IW, Omari TI, Myers JC, et al. Nasopharyngeal pH monitoring in chronic sinusitis patients using a novel four channel probe. Laryngoscope 2004; 114: 1582-1585.

19. Jecker P, Orloff LA, Wohlfeil M, et al. Gastroesophageal reflux disease (GERD), extraesophageal reflux (EER) and recurrent chronic rhinosinusitis. Eur Arch Otorhinolaryngol. 2006; 263: 664667.

20. Kibblewhite DJ, Morrison MDA. Double-blind controlled study of the efficacy of cimetidine in the treatment of the cervical symptoms of gastroesophageal reflux. J Otolaryngol 1990; 19: 103-109.

21. Kleemann D, Nofz S, Plank I, et al. Gastroesophageal reflux as a cause for delayed healing process after FESS? HNO 2005; 53: $333-$ 336 .

22. DiBaise JK, Olusola BF, Huerter JV, et al. Role of GERD in chronic resistant sinusitis: A prospective, open label, pilot trial. Am J Gastroenterol 2002; 97: 843-850.

23. Pincus RL, Kim HH, Silvers S, et al. A study of the link between gastric reflux and chronic sinusitis in adults. Ear Nose Throat $\mathrm{J}$. 2006; 85: 174-178

24. Dinis P.B., Subtil J. Helicobacter pylori and laryngopharyngeal reflux in chronic rhinosinusitis. Otolaryngol - Head and Neck Surg 2006; 134: 67-72

25. Delehaye E, Dore MP, Bozzo C, et al. Correlation between nasal mucociliary clearance time and gastroesophageal reflux disease: our experience on 50 patients. Auris Nasus Larynx 2009; 36: 157 161.

26. Wise SK, Wise JC, DelGaudio JM. Association of nasopharyngeal and laryngopharyngeal reflux with postnasal drip symptomatology in patients with and without rhinosinusitis. Am J Rhinol. 2006; 20: 283-289.

EP Flook

17 Willow Way

Manchester, M20 6JT

United Kingdom

Tel: +49-79-3208 1662

E-mail: edflook@yahoo.com 